\title{
Hobbes and the prophet Samuel on leviathan government
}

\author{
Arye L. Hillman
}

Received: 25 March 2009 / Accepted: 22 April 2009 / Published online: 7 May 2009

(C) Springer Science+Business Media, LLC 2009

\begin{abstract}
Thomas Hobbes' Leviathan is one of the most important treatises in the history of political economy and has influenced writings on constitutional economics and public choice. In his treatise, Hobbes proposed the desirability of voluntary subjugation to an authoritarian ruler. Hobbes appealed to the authority of the prophet Samuel to make his case for Leviathan, a precedent that has remained unquestioned for some 350 years. Yet Samuel clearly warned against the dangers of appointing an all-powerful king. Hobbes's argument in favor of Leviathan thus demands an authority other than Samuel.
\end{abstract}

Keywords Prophet Samuel · Hobbes · Leviathan

JEL Classification B11 $\cdot$ B32

\section{Hobbes' Leviathan}

The book Leviathan by Thomas Hobbes, first published in 1651, is a centerpiece of western theory of government. In Leviathan (the Hebrew word for whale), Hobbes made the case for an all-encompassing authoritarian ruler who, by owning all property and controlling all people, would save a society from the anarchy that would otherwise be the consequence of base human nature. ${ }^{1}$ Hobbes' case for the leviathan has profoundly influenced writings on constitutional economics and public choice. Buchanan (1975) for example formulated the case for constitutional restraint against the background of the leviathan. The role of leviathan in public choice is summarized in Mueller (2003) and Hillman (2009).

\footnotetext{
${ }^{1}$ Grossman (2002) provided a general-equilibrium restatement of Hobbes' case for the leviathan.
}

A.L. Hillman $(\bowtie)$

Department of Economics, Bar-Ilan University, Ramat Gan 52900, Israel

e-mail: hillman@mail.biu.ac.il 


\section{Hobbes and the prophet Samuel}

In Leviathan, Hobbes referred extensively to biblical writings-Hobbes' father was a vicar and he had been educated in a church school. In making his arguments, Hobbes relied on the method of authority whereby claims are substantiated by the precedent of support from prior authorities. In justifying his proposal that people should rationally wish to subject themselves to the absolute authority of a leviathan, Hobbes used the Book of Samuel I, which relates that representatives of the 12 tribes of Israel approached the prophet Samuel to request a king "as other peoples had". The request of the tribes of Israel to Samuel for a king was presented by Hobbes as exemplary of the rationality of voluntary self-subjugation to an all-encompassing ruler. ${ }^{2}$

Samuel responded to the request for a king by describing how the king would exercise authority. Samuel pointed out to the representatives of the tribes that a king would take their sons and use them as personal charioteers and that their daughters would be taken by the king for service as perfumers, cooks, and bakers. The king would take fields and vineyards, and the best olive trees, and give them to those close to him. He would take ten percent of the people's animals and other wealth; and the people would be his servants. Hobbes (1651/1962, pp. 155-156) repeated Samuel's response in detail. The subheading used by Hobbes when describing Samuel's response was The Rights of the Monarch from Scripture. Samuel's response to the tribes was thus presented by Hobbes as defining the rights of the leviathan.

In quoting Samuel's response to the request for a king, Hobbes stopped short of continuing Samuel's words for an additional sentence wherein Samuel declared:

you will regret the day that you chose kings to rule over you. ${ }^{3}$

Thus Samuel did not provide a precedent for an all-encompassing authoritarian ruler. Samuel on the contrary warned against the loss of liberty and of the anguish and regret that would follow subjugation to the authority of a king.

\section{Anarchy and freedom}

Hobbes' view of desirable government contrasts with that of John Locke (1690/1960). Locke viewed society on a scale from subjugation to personal freedom and declared personal freedom to be the ideal. Hobbes feared anarchy. ${ }^{4}$ The society of the tribes of Israel had not been anarchic. Nor were the representatives of the tribes anarchically contesting from which tribe a king should be chosen. Rather the representatives came to ask that a king be appointed in order to coordinate defense. ${ }^{5}$ Samuel responded that having a king would come at the cost

\footnotetext{
${ }^{2}$ Before Samuel, there had been judges, who judged according to the law that had been given in Sinai: with the law given, governance had been through judges without a king and there was therefore no need for a king, neither to make laws and nor to enforce the law. After Samuel, there were prophets, who were often the conscience of the kings, who departed from the behavior proscribed in the law. Samuel overlapped in being the last judge and the first prophet.

${ }^{3}$ Literally in the original Hebrew: "You will cry out on that day when you confront kings that you chose for yourselves". Samuel Book I, 8, 18.

${ }^{4}$ See Rowley (2001) on the contrary positions of Hobbes and Locke, and Hillman (2009, Chap. 10).

${ }^{5}$ The representatives of the tribes declared that they wanted a king who "will go out before us and we shall fight our wars [in unity]". Samuel Book I, 8, 20.
} 
of loss of personal liberty and he predicted that the king would appropriate wealth for himself and would take and redistribute the people's property (the fields, vineyards, and olive trees that are the wealth of an agrarian society) to those close to him. Hobbes was ostensibly aware of Samuel's warning against choosing a king. Hobbes may have read Samuel in Hebrew but also the authorized King James English translation of the bible had been completed in 1611. The words spoken by Samuel are there translated as:

And ye shall cry out in that day because of your king which ye shall have chosen you. ${ }^{6}$

\section{Hobbes on liberty}

Hobbes devoted a chapter in Leviathan to "the liberty of subjects". He pointed out that, although liberty is oft times valued, nonetheless liberty is not a right of ordinary people, for "the liberty which writers praise, is the liberty of sovereigns, not of private men." Hobbes declared that fear and liberty are "consistent", since fear of the leviathan would civilize people by restraining their evil inclinations toward one other. To illustrate his argument, Hobbes used the analogy of a ship that would sink if the passengers did not throw their possessions overboard. People were at liberty not to throw their possessions overboard; that is, they were free not to give ownership of their possessions to the leviathan. However, if possessions were not thrown overboard, the ship would sink and possessions as well as life would be lost. The influence of the book of Jonah is evident; Hobbes mentioned Jonah. ${ }^{7}$

\section{Does Hobbes' deception matter?}

Does Hobbes' deception in misusing the words of the prophet Samuel matter? A position can be taken that Hobbes' misuse of Samuel can be dismissed as uninteresting on the grounds that "Hobbes was not seeking to mislead as to make the strongest case he could for his argument". ${ }^{8}$ Adherents to this view are prepared to accept deception as permissible in intellectual enquiry. They would not provide a forum for pointing out Hobbes' deception. Others including myself may take the view that deception should be revealed, particularly when someone's position is misrepresented, as was the case with regard to Hobbes' misuse of Samuel as a precedent in support of the leviathan.

\section{References}

Buchanan, J. M. (1975). The limits of liberty: between anarchy and leviathan. Chicago: University of Chicago Press.

\footnotetext{
${ }^{6}$ The "you" at the end of the sentence renders this translation grammatically inappropriate. The last word in the original Hebrew is לכם "for yourselves". See my translation in footnote 3.

${ }^{7}$ The Book of Jonah describes how, when called upon to go to the city of Nineveh to warn the inhabitants to repent from evil, Jonah instead boarded a ship in the port of Jaffa with the intention to flee elsewhere. When a storm engulfed the ship, the passengers threw their possessions overboard, in the hope of saving themselves by lightening the load carried by the ship. The storm however only subsided after Jonah asked that he be thrown overboard. The analogy sought by Hobbes is not present. Throwing possessions overboard did not save the passengers and crew of the ship and indeed was unnecessary. Jonah's change in behavior saved the people on the ship.

${ }^{8}$ Private communication to the author, 21 January 2009, from Craufurd Goodwin, Duke University.
} 
Grossman, H. I. (2002). "Make us a king": Anarchy, predation and the state. European Journal of Political Economy, 18, 31-46.

Hillman, A. L. (2009). Public finance and public policy: responsibilities and limitations of government (2nd ed.). Cambridge: Cambridge University Press.

Hobbes, T. (1651/1962). Leviathan (or the matter, form and power of a commonwealth ecclesiastical and civil). New York: Collier Books.

Locke, J. (1690/1960). Two treatises of government. P. Lazlett (Ed.). Cambridge: Cambridge University Press.

Mueller, D. C. (2003). Public choice III. Cambridge: Cambridge University Press.

Rowley, C. K. (2001). Constitutional political economy and civil society. In R. Mudambi, P. Navarra, \& G. Sobbrio (Eds.), Rules and reason: perspectives on constitutional political economy (pp. 69-96). Cambridge: Cambridge University Press. 